\title{
A new species of Atrimitra Dall, 1918 (Gastropoda: Mitridae) from seamounts of the recently created Nazca-Desventuradas Marine Park, Chile
}

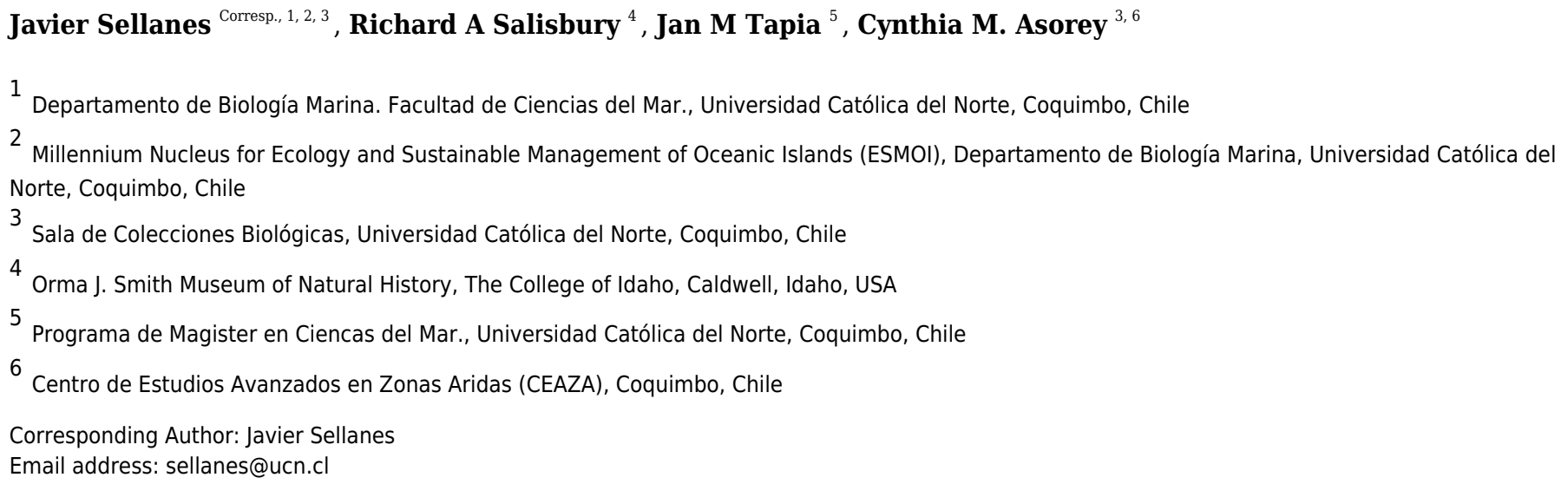

We describe Atrimitra isolata sp. n. (Gastropoda: Mitridae), collected on the summit of seamounts ( $200 \mathrm{~m}$ water depth) in the vicinity of Desventuradas Islands, Chile insular territory. Additionally, we provide some insight into the habitat of this new species based on underwater imagery taken with a remotely operated vehicle (ROV). Atrimitra isolata sp. $\mathrm{n}$. is characterized by its small size (up to $26 \mathrm{~mm}$ ), elongate-ovate shape, solid shell and smooth appearance. It has a base brown color, with some specimens being tan or yellow. It is morphologically related to counterparts from shallow depths on the west coast of North, Central and South America (i.e., Atrimitra idae, Atrimitra orientalis and Atrimitra semigranosa), but has no affinities with species of the family reported from around Easter Island, on the far western side of the Salas y Gómez ridge (e.g., Strigatella flavocingulata, Imbricariopsis punctata and Neocancilla takiisaoi), or with other Indo-Pacific species. The present contribution adds to the knowledge of the poorly studied fauna of the seamounts in the southern portion of the Nazca ridge and easternmost section of the Sala y Gómez ridge, an area characterized by the high degree of endemism of its benthic fauna, and now protected within the large and newly created Nazca-Desventuradas Marine Park. 


\section{A new species of Atrimitra Dall, 1918 (Gastropoda: Mitridae) \\ 2 from seamounts of the recently created Nazca- \\ 3 Desventuradas Marine Park, Chile.}

4

5

6

7

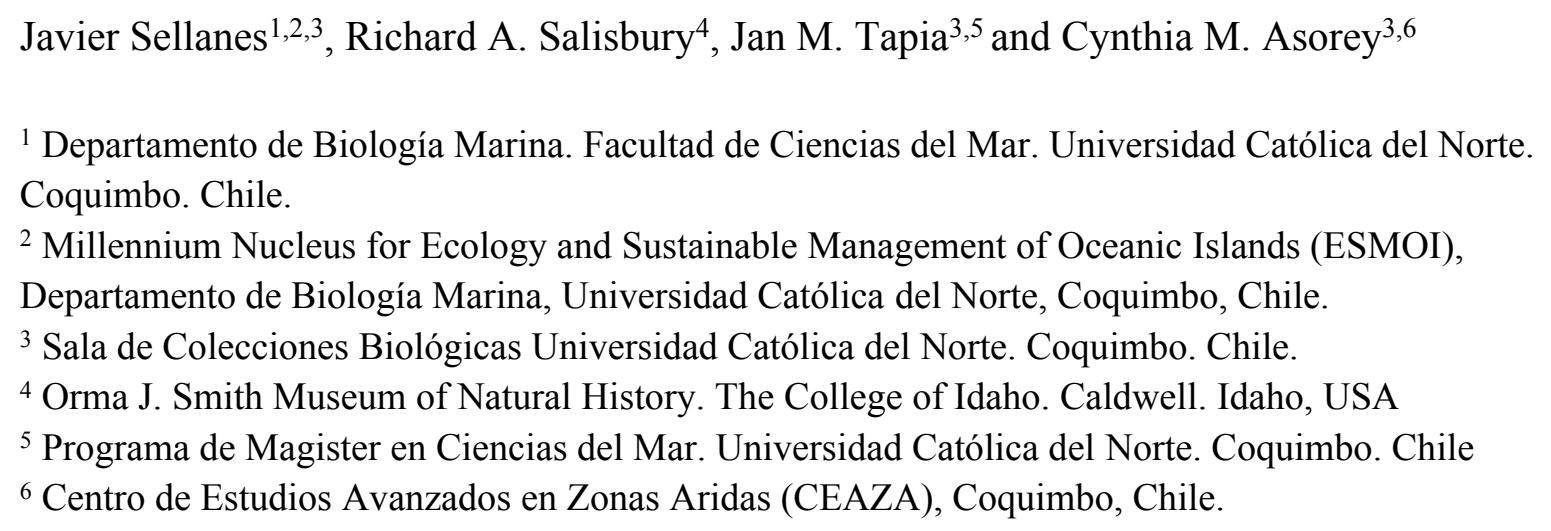

\section{Abstract}

We describe Atrimitra isolata sp. n. (Gastropoda: Mitridae), collected on the summit of seamounts ( $\sim 200$ $\mathrm{m}$ water depth) in the vicinity of Desventuradas Islands, Chile insular territory. Additionally, we provide some insight into the habitat of this new species based on underwater imagery taken with a remotely operated vehicle (ROV). Atrimitra isolata sp. n. is characterized by its small size (up to $26 \mathrm{~mm}$ ), elongate-ovate shape, solid shell and smooth appearance. It has a base brown color, with some specimens being tan or yellow. It is morphologically related to counterparts from shallow depths on the west coast of North, Central and South America (i.e., Atrimitra idae, Atrimitra orientalis and Atrimitra semigranosa), but has no affinities with species of the family reported from around Easter Island, on the far western side of the Salas y Gómez ridge (e.g., Strigatella flavocingulata, Imbricariopsis punctata and Neocancilla takiisaoi), or with other Indo-Pacific species. The present contribution adds to the knowledge of the poorly studied fauna of the seamounts in the southern portion of the Nazca ridge and easternmost section of the Sala y Gómez ridge, an area characterized by the high degree of endemism of its benthic fauna, and now protected within the large and newly created Nazca-Desventuradas Marine Park. 


\section{Introduction}

38

39

40

41

42

43

44

45

46

47

48

49

50

51

52

53

54

55

56

57

58

59

60

61

62

63

64

65

66

67

68

69

70

71

72

73

74

75

76

77

78

79

80
In 2015, Chile created the large Nazca-Desventuradas Marine Park (NDMP), covering almost 300,000 $\mathrm{km}^{2}$ of this remote part of the SE Pacific. Comprising San Ambrosio and San Félix Islands (known as Desventuradas Islands), and the seamounts located northwest of them, at the intersection of the Salas y Gómez and the Nazca Ridges, this park aims to protect the unique marine fauna inhabiting this area, recognized as a hotspot of species endemism (Fernández et al., 2014; Friedlander et al., 2016). As an example, the estimated endemism of fishes, one of the few groups for which enough information exists, is about $40 \%$ (Friedlander et al., 2016). Conversely, information for invertebrates in the area is sparse. Most of the existing references are associated with research expeditions carried out between 1973 and 1987 by the former Soviet Union, and limited to the area beyond Chilean jurisdiction east of $\sim 83^{\circ} \mathrm{W}$ (Mironov and Detinova 1990; Parin et al., 1997). Even with this limited information, endemism estimations in general are outstandingly high, reaching $\sim 46 \%$ for the benthic biota (Parin et al., 1997). For mollusks, these authors report, for the 22 seamounts along the Salas y Gomez and Nazca ridges explored, a total of: one species of Polyplacophora, 27 species of Gastropoda (most of them of the superfamily Conoidea), seven species of Bivalvia, and seven species of Cephalopoda. The latter corresponding to pelagic species, collected most probably during the transit of the trawl nets through the water column. In Parin et al. (1997), as well as in subsequent malacological studies in the area, no representatives of the family Mitridae have ever been mentioned. However, in the westernmost side of the Salas y Gómez ridge, at Rapa Nui (Easter Island), Osorio (2018) mentioned the occurrence of the following three Mitridae species: Strigatella flavocingulata (Lamy, 1938), Imbricariopsis punctata (Swainson, 1821) and Neocancilla takiisaoi (Kuroda, 1959). The two species of the family reported for continental Chile are: Atrimitra orientalis (Griffith and Pidgeon, 1834) (see Marincovich, 1973) and Atrimitra semigranosa (von Martens, 1897) (see Keen, 1971), both from northern Chile, $\sim 20-22^{\circ} \mathrm{S}$.

In the present study, we revise the Mitridae reported for the region, but with emphasis in continental and insular marine jurisdictional areas of Chile, and describe a new species of Atrimitra collected on the summit of seamounts within the NDMP. Insight into the habitat of the new species, based on underwater imagery, is also provided.

\section{Abbreviations}

$\mathrm{AL}$

Aperture length (mm).

ANSP

Academy of Natural Sciences of Drexel University, Philadelphia, USA.

CIDA

d

$\mathrm{L}$

Orma J. Smith Museum of Natural History, The College of Idaho, USA.

Dead collected specimen.

Length (mm)

lv Live collected specimen.

MNHNCL Museo Nacional de Historia Natural, Chile.

NDMP

NMW

RAS

ROV

SCBUCN

SDMNH

$\mathrm{W}$

Nazca Desventuradas Marine Park.

National Museum of Wales, Cardiff

Richard A. Salisbury

Remotely operated underwater vehicle.

Sala de Colecciones Biológicas de la Universidad Católica del Norte, Chile.

San Diego Museum of Natural History, San Diego, USA.

Width (mm). 
81

82

83

84

85

86

87

88

89

90

91

92

93

94

95

96

97

98

99

100

101

102

103

104

105

106

107

108

109

110

111

112

113

114

115

116

117

118

119

120

121

122

123

\section{Materials \& Methods}

Material collection and in situ observations: From October to November 2016, a multidisciplinary oceanographic cruise (CIMAR 22 "Oceanic Islands") was carried out on the research vessel AGS61Cabo de Hornos. The aim of the cruise was to study benthic habitats and fauna of unexplored seamounts of the Juan Fernández and Desventuradas Ecoregion (Fig. 1) (Spalding et al. 2007; ecoregion number 179). Within the newly created NDMP, six seamounts were visited and six stations were also studied around San Ambrosio and San Felix islands (i.e., Desventuradas Islands) (Fig. 1). Unless weather or sea condition precluded it, the protocol for the benthic survey consisted of a first visual observation of the study site using a ROV (Commander MK2; Mariscope Meerestechnik, Kiel, Germany) equipped with a HD Camcorder (Panasonic SD 909) and laser pointers (10 cm apart), followed by sampling with an Agassiz trawl. The latter consisted of a metal frame with a mouth of $1.5 \mathrm{~m} \times 0.5 \mathrm{~m}$ (width $\times$ height) fitted with a net of 12-mm mesh at the cod end, operated in10-min. hauls (bottom contact), at $\sim 3$ knots. Collected specimens were preserved in $95 \%$ ethanol. Type material as voucher specimens were deposited in the MNHNCL, SCBUCN, ANSP and CIDA, including specimens prepared for scanning electron microscope (SEM) analysis. Sample collection was performed under permission Res. Ext N41/2016 from SERNAPESCA (Chile) to Universidad Católica del Norte.

The radula and protoconch were examined with a Hitachi SU3500 SEM at the Microscopy Laboratory of the Facultad de Ciencias del Mar, Universidad Católica del Norte, Coquimbo, Chile. A radula from an adult specimen, that was broken for this purpose, was extracted by dissection of the soft parts and cleaned in a 1:50 commercial bleach solution. The examined protoconch was from the same specimen. The radula and the protoconch were dried in a Tousimis, Samdri-780A critical-point dryer using $\mathrm{CO}_{2}$, mounted on bronze stubs and coated with gold in a JEOL JFC-100 evaporator. Description of the radula followed the formula proposed by Cernohorsky (1970), which uses the number of cusps on the lateral and central rachidian plates.

Genomic DNA was extracted from samples SCBUCN 7030, SCBUCN7031 and SCBUCN7033 (see type material), from $20 \mathrm{mg}$ of foot tissue of each, and using an E.Z.N.A. ${ }^{\circledR}$ Tissue DNA kit (Omega, Bio-Tek). In order to amplify partial sequences of the histone $3(\mathrm{H} 3)$ nuclear gene and the mitochondrion cytochrome oxidase I (COI) gene, the pairs of primers H3F (ATGGCTCGTA CCAAGCAGACVGC) and H3R (ATATCCTTRG GCATRATRGTGAC) (Colgan et al., 2000) and HCO-1490 (GGTCAACAAA TCATAAAGAYATGYG) and LCO-2198 (TAAACTTCAGGG TGACCAAARAAYCA) (Folmer et al., 1994) were used, respectively. The PCR profile for COI started with $5 \mathrm{~min}$ at $95^{\circ} \mathrm{C}$, followed by 40 cycles of denaturation at $95{ }^{\circ} \mathrm{C}(1 \mathrm{~min})$, annealing at $50{ }^{\circ} \mathrm{C}(1 \mathrm{~min})$, and elongation at $72{ }^{\circ} \mathrm{C}(2 \mathrm{~min})$, with a final elongation phase at $72{ }^{\circ} \mathrm{C}(13 \mathrm{~min})$. A similar PCR profile was set for $\mathrm{H} 3$ (annealing at $55^{\circ} \mathrm{C}$ ). Since amplification of the products obtained with both pairs of primers failed, the integrity of genomic DNA samples from all individuals was analyzed by agarose gel electrophoresis, following the procedure described in Pereira et al. (2011). While a tight band (minimal smearing and no banding patterns) of high molecular weight would indicate a high-quality genomic DNA, smearing would indicate degraded DNA, and thus low quality (Pereira et al., 2011). In our case, the visualization in the agarose gel showed smearing and no band, suggesting degradation of the DNA, probably caused by suboptimal preservation of the tissue.

Peer] reviewing PDF | (2018:11:32763:3:0:NEW 4 Nov 2019) 
124 Nomenclature: The electronic version of this article in Portable Document Format (PDF) will represent a

125

126

127

128

129

130

131

132

133

134

\section{5}

136

137

138

139

140

141

142

143

144

145

146

147

148

149

150

151

152

153

154

155

156

157

158

159

160

161

162

163

164

165

166 published work according to the International Commission on Zoological Nomenclature (ICZN), and hence the new names contained in the electronic version are effectively published under that Code from the electronic edition alone. This published work and the nomenclatural acts it contains have been registered in ZooBank, the online registration system for the ICZN. The ZooBank LSIDs (Life Science Identifiers) can be resolved and the associated information viewed through any standard web browser by appending the LSID to the prefix http://zoobank.org/. The LSID for this publication is: LSID: Atrimitra isolata sp. n. urn: 1sid:zoobank.org:pub:787A4D2A-260C-49BC-B8B0-0665F2BF6108. The online version of this work is archived and available from the following digital repositories: PeerJ, PubMed Central and CLOCKSS.

\section{Results}

\section{Systematics account}

Superfamily: Mitroidea Swainson, 1831

Family: MITRIDAE Swainson, 1831

Subfamily: Mitrinae Swainson, 1831

Genus: Atrimitra Dall, 1918

Type species: Mitra idae Melvill, 1893 by original designation.

Atrimitra isolata sp. n. Sellanes and Salisbury

Figs. 2(A-H), 3(A-E)

Diagnosis: Main characteristics of the shell are the small size to $26 \mathrm{~mm}$, elongate-ovate shape, solid, with smooth appearance. Base color brown with some specimens tan or yellow in color.

Description: Medium sized shell up to $26 \mathrm{~mm}$, solid, elongate-ovate. Protoconch multispiral, of 4-5 large brown glassy bulbous whorls (Fig. 2D, 3C-D). Spire whorls convex, post nuclear whorl with numerous weak, beaded, axial ribs, with 3-4 strong, deep punctate grooves, spiral grooves bisect the axial ribs giving the first whorl a fenestrate sculpture, sculpture changes rapidly on the early whorls, axial ribs become nearly obsolete with spiral punctate grooves varying in number and spacing (Fig. 3E). Penultimate whorl with 6 to 8 spiral grooves of which 3 to 4 are deeply punctate, the axial ribs are flattened. Suture distinct but not deeply incised, last adult whorl with 12-14 shallow spiral grooves, half with punctations in the grooves, last adult whorl sculpture changes on the lower half to wide, 10-12 flat spiral cords separated by spiral grooves, the spiral cords are oblique on the fasciole. Aperture of medium width, outer lip gently rounded and smooth, interior of aperture smooth, columella with 4 columellar folds, siphonal canal short and wide, lacking a siphonal notch. Aperture length greater than half the shell length. Base color brown with some specimens tan or yellow in color. Aperture brown with a faint purple tint. Foot, siphon and eye stalks of the fresh collected animal, white, becoming black when fixed in ethanol. Based on the cusp number the formula of the radula is: 15-5-15, with the lateral rachidian cusp number count $+/-1$ (Fig. 3E).

\section{Type material:}

Peer) reviewing PDF | (2018:11:32763:3:0:NEW 4 Nov 2019) 
168 Holotype MNHNCL 203730 (Fig. 2 A-D), L: $20.4 \mathrm{~mm}, \mathrm{~W}: 7.3 \mathrm{~mm}$, AL: $10.2 \mathrm{~mm}$, seamount off coast of

169 Chile, CIMAR 22 cruise, Station SF9, Lat. -25.7774, Long. -83.163, October 27, 2016, C22 SSF9 A,

170 trawled, $200 \mathrm{~m}$ water depth, lv.

171

172

173

174

175

176

177

178

179

180

181

182

183

184

185

186

187

188

189

190

191

192

193

194

195

196

197

198

199

200

201

202

203

204

205

206

207

208

209

210

211

212

Additional type material:

paratype 1 MNHNCL 203731 (Fig. 2E-F), L: $25.8 \mathrm{~mm}, \mathrm{~W}: 9.2 \mathrm{~mm}$, AL: $13.4 \mathrm{~mm}$, same as holotype, lv. paratype 2 CIDA 126,574 (Fig. 2G-H), L: $21.5 \mathrm{~mm}, \mathrm{~W}: 8.1 \mathrm{~mm}$, AL: $11.4 \mathrm{~mm}$, same as holotype, lv. paratype 3 ANSP 476798, L: $16.1 \mathrm{~mm}, \mathrm{~W}: 6.0 \mathrm{~mm}$, AL: $8.1 \mathrm{~mm}$, same as holotype, lv. paratype 4 MNHNCL 203732, L: $19.1 \mathrm{~mm}$, W: $7.0 \mathrm{~mm}$, AL: $10.8 \mathrm{~mm}$ (with predator holes in shell and limpet scars on the columella and aperture), same as holotype, lv.

paratype 5: SCBUCN 7627, L: $11.8 \mathrm{~mm}, \mathrm{~W}: 4.9 \mathrm{~mm}$, AL: $6.7 \mathrm{~mm}$, same as holotype, lv. paratype 6 SCBUCN 6953, L20.4 mm, W: $7.5 \mathrm{~mm}$, same as holotype, $\mathrm{d}$. paratype 7 SCBUCN 7029, L: $20.1 \mathrm{~mm}, \mathrm{~W}: 7.4 \mathrm{~mm}$, same as holotype, lv. paratype 8 SCBUCN 7033, L: $22.9 \mathrm{~mm}, \mathrm{~W}: 8.4 \mathrm{~mm}$, same as holotype (with attached limpet), lv. paratype 9 SCBUCN 7038, L: $19.6 \mathrm{~mm}, \mathrm{~W}: 7.5 \mathrm{~mm}$, Seamount SF5, lv. paratype 10 SCBUCN 6952a, L: $21.2 \mathrm{~mm}, \mathrm{~W}: 7.5 \mathrm{~mm}$, same as holotype, d. paratype 11 SCBUCN 6952b, L: $21.7 \mathrm{~mm}, \mathrm{~W}: 8.0$, same as holotype, lv. paratype 12 SCBUCN 7031, L: $17.1 \mathrm{~mm}, \mathrm{~W}: 7.0 \mathrm{~mm}$, Seamount SF6, lv. paratype 13 SCBUCN 7030 (Fig. 3A-E), L: 21.4, W: $8.0 \mathrm{~mm}$, same as holotype, lv. paratype 14 SCBUCN $6946 \mathrm{a}, \mathrm{L}: 16.2 \mathrm{~mm}, \mathrm{~W}: 6.2 \mathrm{~mm}$, same as holotype, lv. paratype 15 SCBUCN 6946b, L: $19.1 \mathrm{~mm}, \mathrm{~W}: 7.0 \mathrm{~mm}$, same as holotype, lv. paratype 16 SCBUCN 6946c , L: $20.2 \mathrm{~mm}, \mathrm{~W}: 7.6 \mathrm{~mm}$, same as holotype, lv. paratype 17 SCBUCN 6946d, L: $18.8 \mathrm{~mm}, \mathrm{~W}: 7.7 \mathrm{~mm}$, same as holotype (with drill hole), d. paratype 18 SCBUCN 6947a, L: $22.4 \mathrm{~mm}$, W: $8.8 \mathrm{~mm}$, Seamount SF5, lv. paratype 19 SCBUCN 6947b, L: $22.9 \mathrm{~mm}$, W: $8.8 \mathrm{~mm}$, Seamount SF5, d. paratype 20 SCBUCN 6947c , L: $23.4 \mathrm{~mm}$, W: $9.0 \mathrm{~mm}$, Seamount SF5, lv.

Comparative material: Atrimitra idae (Melvill, 1893), holotype NMW 1955.158.00100, Point Loma, Lower California, USA, Strigatella coronadoensis Baker and Spicer, 1930, holotype SDMNH 44409667, southeastern end of Los Coronados Islands, Lower California, Mexico (Fig. 4A-C), Atrimitra semigranosa, collected near Arica, Parinacota Region, Chile, RAS collection (Fig 4D-F), Atrimitra orientalis, Lobos de Afuera Islands, Peru, RAS collection (Fig. 4G-I), two lots of specimens including Atrimitra orientalis and Atrimitra semigranosa, SCBUCN-7617, Caleta Los Verdes, Iquique, and SCBUCN-7618, El Ñajo, Iquique, Chile.

Type locality: Seamount SF9, Lat. -25.7774, Long. -83.3163, Sta. C22SSF9-A, 27 October 2016, at 200 $\mathrm{m}$ water depth.

Distribution and habitat: Specimen samples come from the summit of three seamounts within the NDMP: SF5 (Lat. -25.4272, Long. -81.8806, $180 \mathrm{~m}$ depth), SF6 (Lat. -25.5535, Long. -82.3963, $176 \mathrm{~m}$ depth), and SF9 (Lat. -25.7774, Long. -83.3163, $200 \mathrm{~m}$ depth). ROV images suggest that the species is also present at nearby seamount SF2 (Lat. -24.7424, Long. -82.5226, $280 \mathrm{~m}$ depth). All these seamounts are located within the NDMP.

For the three seamounts on which the species was collected, the summits of two of them (SF6 and SF9) were explored using a ROV. The summit of SF2 was surveyed with the ROV but roughness of the terrain 
213 precluded trawling. The bottom at SF6 and SF9 was dominated by coarse sand and the presence of maërl-

214 rhodoliths (Fig. 5A and 5B, respectively), scattered rocky outcrops were also spotted at both sites. Habitat

215 at SF2 differed by the predominance of hard substrates (Fig. 5C). Although about 20 mollusk taxa were

216 found in total at the three collection sites (SF5, SF6 and SF9), species that co-occurred with A. isolata $\mathrm{sp}$.

217 n. at all sites were Architectonica karsteni Rutsch, 1934 and Chryseofusus kazdailisi (Fraussen and

218 Hadorn, 2000).

219

220

221

222

223

224

225

226

227

228

229

230

231

232

233

234

235

236

237

238

239

240

241

242

243

244

245

246

247

248

249

250

251

252

253

254

255

\section{Discussion}

Etymology: From isolatus (Latin for isolated) in reference to the remote and isolated geographical location of the four seamounts on which the new species was found.

Species comparisons: The holotype of Atrimitra idae (Fig. 2I), the type species of the genus Atrimitra, measuring $72.1 \mathrm{~mm}$ (Cernohorsky 1976) is much larger than the largest recorded specimen of $A$. isolata sp. n. (paratype 1, $25.8 \mathrm{~mm}$ ). Atrimitra idae is covered with a thick black periostracum which obscures the sculpture and color pattern of the shell. With the periostracum removed $A$. idae, is brown to tan in color. The early whorls are almost always eroded and often covered with a thick encrustation. Cernohorsky (1976) listed Strigatella (Atrimitra) coronadoensis (holotype, Fig. 4A-C) as a synonym of Mitra idae, but this has yet to be confirmed. Strigatella coronadoensis has a tiny bullet-shaped, glassy white protoconch of 4-5 whorls. Atrimitra isolata sp. n. also has a protoconch of 4-5 whorls but these are large, brown, glassy and bulbous. Unlike $A$. idae, the new species has a thin, nearly transparent periostracum, and the sculpture can be seen through it. Sculpture also differs from A. idae, which is ornamented with fine spiral grooves, unevenly spaced on the early whorls, with strong axial grooves and growth lines giving the shell a fenestrate appearance. The spiral grooves grow wider on the last adult whorl and the spiral cords also grow wider on the upper part of the last adult whorl. The spiral cords are more uniform in size on the lower part of that adult whorl and not bisected with as many axial grooves or growth lines. Atrimitra isolata sp. $\mathrm{n}$. is sculptured with widely spaced punctate spiral grooves with fine spiral grooves, usually not punctate that alternate with the deeper punctate grooves. The early whorls are ornamented with shallow axial grooves which form close-set axial ribs. The axial ribs widen and flatten on later whorls. This smoothes the sculpture and makes the shells slippery. The two species live in entirely different habitats, while Atrimitra idae can be found at depths reachable by scuba and in subtidal habitats such as rocks and rubble, the new species lives at depths between 180 and 280 meters on rocky bottoms on seamounts.

Two other Mitridae species have been reported from Chile (Cernohorsky 1976), both formerly in the genus Mitra but now placed in Atrimitra (Fedosov et al., 2018). Both A. semigranosa (Fig. 4D-F) and A. orientalis (Fig. 4G-I), are found in intertidal and subtidal zones associated with rocks, gravel and sand. Atrimitra semigranosa can be easily separated from this new species by the pustulate early whorls, and larger size, up to $46 \mathrm{~mm}$. The shell of $A$. semigranosa is covered with a dark brown periostracum, the shell is brown with the early whorls beaded and light brown in color. The beads become obsolete on later whorls with the shell sculptured with spiral cords that are separated by shallow spiral grooves and bisected by axial grooves, giving the mid-whorls a clathrate appearance, the last adult whorl is ornamented with very fine, close-set spiral grooves which grow larger toward the base of the shell. Atrimitra orientalis is covered with a thick black periostracum and has a much smoother and larger shell, up to $72 \mathrm{~mm}$, that is gray or light brown in color under the periostracum. 
257

258

259

260

261

262

263

264

265

266

267

268

269

270

271

272

273

274

275

276

277

278

279

280

281

282

283

284

285

286

287

288

289

290

291

292

293

294

295

296

297

298

299

300

Atrimitra isolata sp. n. is one of only a few Mitridae reported from Chilean waters. The new species seems to be isolated from the mainland and so far has been found only on the Nazca Plate, where it lives in deep water associated with seamounts. Since the Nazca and Salas y Gómez ridges are still poorly known in terms of their benthic biodiversity, it is only possible to speculate that the new species might be endemic to the area. The multispiral protoconch of $A$. isolata sp. n. suggests a planktotrophic larval development mode, and thus a high potential for dispersion. On the other hand, physical processes determining connectivity patterns in the area are still poorly known. As an example, it has been suggested that the Humboldt Current System, with characteristic cold and nutrient-rich waters could be acting as a barrier, at least separating the biota of this area from the South American coast (Friedlander et al., 2016). Seamounts are also known to generate particular circulation patterns over their summits, which could be contributing in the retention of locally generated larvae (Rogers, 2018). All these factors could be contributing to the isolation of the local fauna and thus to their potential endemism.

The recent publication by Fedosov et al. (2018) defining the phylogeny of the Mitridae has indicated that the genus Atrimitra Dall, 1918 is represented by several species living along the western coasts of North, Central and South America. We have chosen to include the new species in Atrimitra based on the very fine sculpture of the shell. However, further research, including molecular, analysis is still needed to confidently place the new species within the Atrimitra or Isara generic units (Fedosov et al., 2018). Failure in the extraction of genomic DNA of sufficient quality for sequencing the COI and $\mathrm{H} 3$ genes in our specimens could be attributed to deficient tissue preservation. The animal in the preserved specimens was deeply retracted, and considering also that the aperture of the shell is relatively small, probably an amount of ethanol sufficient to avoid DNA degradation did not reach the soft parts.

The number of cusps on the central rachidian plate of the radula is a feature often considered for the taxonomy of Mitridae. For Atrimitra idae, only drawings of the radula have been published (e.g., Cernohorsky, 1970; 1976), and the non-existence of SEM photos and the little detail presented by the drawings of the radula caused confusion in the cusp formula. Radula of $A$. idae drawings show a formula of 28-6-28 or 28-7-28, with the lateral rachidian plates cusp number $+/-3$ counts (due to drawing quality). The central rachidian plate in Mitridae often shows two types of formula. The first type presents an evennumbered set of cusps, where each side of the central rachidian plate has the same number and size of cusps (R. A. Salisbury, pers. obs.). The second type presents a longer central cusp with shorter lateral cusps on each side. This type has an odd number of cusps and $A$. isolata sp. n. is an example of this central rachidian type which has five cusps. However, there are not enough SEM images of radulae of this type (see Fedosov et al., 2018) to make any decisions as to the importance of the cusp count on the central rachidian plate.

It is interesting to note that species of the family Mitridae found around Easter Island, Strigatella flavocingulata (Lamy, 1938), Imbricariopsis punctata (Swainson, 1821) and Neocancilla takiisaoi (Kuroda, 1959), reviewed in Osorio (2018), on the far western side of the Salas y Gómez ridge, are all Indo-Pacific species, with ranges across the Indian and Pacific Ocean. The new species has no morphological affinities with them and available evidence suggests that it is found only on seamounts of this region, which hosts a fauna characterized by the high levels of endemism (Friedlander et al., 2016). An interesting ecological observation is that some specimens of $A$. isolata sp. n. show drill holes, perhaps from Muricidae, Naticidae or other predators. Shells of live and dead specimens sometimes present scars from a hipponicid limpet (Fig. 6). Although we cannot confirm identity, similar limpets are also found attached to spines of the urchin Stereocidaris nascaensis (JM Tapia pers. obs.), suggesting that the

Peer) reviewing PDF | (2018:11:32763:3:0:NEW 4 Nov 2019) 
301 relationship with $A$. isolata sp. n. is just an opportunistic commensalism. Regarding potential food

302 sources of $A$. isolata sp. n., it has been observed that rhodoliths recovered from SF6 and SF9 seamounts

303 were profusely bored by sipunculans of the genus Aspidosiphon (JM Tapia, pers. obs.). Sipunculans have

304 been often reported as a prey for Mitridae (Ponder, 1998). For further details of the habitat and ecological

305 aspects of these seamounts, refer to Easton et al. (2019).

306

307

308

309 We describe Atrimitra isolata sp. n. from seamounts near Desventuradas Islands, at the intersection of the

310 Nazca and Salas y Gómez Ridges. Although the region is still poorly studied in terms of its benthic

311 biodiversity, the new species has so far been found only in this area. Available evidence suggests that the

312 new species is more closely related to eastern Pacific Mitridae and not to other central Pacific or Indic

313 Ocean counterparts. Further molecular analysis is still needed to properly place the new species within the

314 Atrimitra or Isara generic units. The present contribution adds to the knowledge of the fauna of

315 seamounts of the Salas y Gómez and Nazca Ridges, an area known by its high levels of endemism, and

316 part of which is now protected within the large and newly created NDMP.

317

318

319 Acknowledgments

320

321 For their assistance at sea we would like to thank the Captain and crew of R/V Cabo de Hornos of the

322 Chilean Navy, and the scientific personnel participating in the CIMAR 22 cruise. Special thanks also go

323 to Erin Easton, Ariadna Mecho and Jorge Avilés for their help during collection, handling and curation of

324 the specimens, and to Maria S. Romero for helping with the SEMs. We are grateful to Dr. Matthias Gorny

325 from OCEANA who piloted the ROV that obtained the images of the habitat at the seamounts surveyed in

326 this study. Marina Fuentes (MZUC), Oscar Gálvez (MNHNCL) and Guillermo Guzmán (Universidad

327 Arturo Prat, Iquique, Chile) provided additional information and material on Chilean Mitridae. Our

328 appreciation to John P. Wolff for checking grammar of this manuscript. We also acknowledge Dr.

329 William "Bill” H. Clark, director of the Orma J. Smith Museum of Natural History for his contributions

330 and help with this work. Bruce Marshall, Alexander Fedosov and an anonymous reviewer are also

331 thanked for providing constructive insight that much improved the article.

332

333

334

335 Cernohorsky WO. 1970. Systematics of the Families Mitridae and Volutomitridae (Mollusca:

336 Gastropoda). Bulletin of the Auckland Institute and Museum 8:1-190.

337

338

339

Colgan DJ, Ponder WF, Eggler PE. 2000. Gastropod evolutionary rates and phylogenetic relationships assessed using partial 28S rDNA and histone H3 sequences. Zoologica Scripta 29:29-63.

340

Cernohorsky WO. 1976. The Mitridae of the World. Part 1. The Subfamily Mitrinae. Indo-Pacific Mollusca 3 (17):273-528. 
341

342

343

344

345

346

347

348

349

350

351

352

353

354

355

356

357

358

359

360

361

362

363

364

365

366

367

368

369

370

371

372

373

374

375

376

377

378

379

380

381

382

383

Easton EE, M, Gorny M, Mecho A, Sellanes J, Gaymer CF, Splading HL, Aburto J. 2019. Chile and the Salas y Gómez Ridge. In: Loya Y, Puglise KA, Bridge TCL, eds. Mesophotic Coral Ecosystems. Springer. 1024pp. DOI: 10.1007/978-3-319-92735-0

Fedosov A, Puillandre N, Herrmann M, Kantor Y, Oliverio M, Dgebuadze P, Modica MV, Bouchet P. 2018. The collapse of Mitra: molecular systematic and morphology of the Mitridae (Gastropoda: Neogastropoda). Zoological Journal of the Linnean Society 183 (2): 253-337. DOI:10.1093/zoolinnean/zlx073

Fernández M, Pappalardo P, Rodríguez-Ruiz MC and Castilla JC. 2014. Synthesis of the state of knowledge about species richness of macroalgae, macroinvertebrates and fishes in coastal and oceanic waters of Easter and Salas y Gómez islands. Latin American Journal of Aquatic Research 42 (4):760-802.

Folmer O, Black M, Hoeh W, Lutz R, Vrijenhoek R. 1994. DNA primers for amplification of mitochondrial cytochrome c oxidase subunit I from diverse metazoan invertebrates. Molecular Marine Biology and Biotechnology 3:294-299.

Friedlander AM, Ballesteros E, Caselle JE, Gaymer CF, Palma AT, Petit I, Varas E, Muñoz-Wilson A, Sala E. 2016. Marine Biodiversity in Juan Fernández and Desventuradas Islands, Chile: Global Endemism Hotspots. PLoS One. 11:e0145059. DOI: 10.1371/journal.pone.0145059

International Commission on Zoological Nomenclature. 1999. International Code of zoological nomenclature. Fourth edition. Available at: http://www.iczn.org/iczn/index.jsp (accessed on November 12, 2018).

International Commission on Zoological Nomenclature. 2008. Proposed amendment of articles 8, 9 , 10, 21 and 78 of the international code of zoological nomenclature to expand and refine methods of publication. Bulletin of Zoological Nomenclature 65:265-275.

Keen, MA. 1971. Sea Shells of Tropical West America: Marine Mollusks from Baja California to Peru. Edition 2. Stanford.1064pp.

Marincovich L .1973. Intertidal mollusks of Iquique, Chile. Bulletin of the Natural History Museum of Los Angeles County 16:1-49.

Mironov AN, NN Detinova. 1990. Bottom fauna of the Nazca and Sala-y-Gomez ridges. In: Mironov AN, Rudjakov JUA, editors. Plankton and Benthos from the Nazca and Sala-y-Gomez Submarine Ridges. Moscow: Nauka, p 269-278 (in Russian).

Osorio C. 2018. Lista de los moluscos de Isla de Pascua (Rapa Nui) Chile, en el Pacifico sur. Boletín del Museo Nacional de Historia Natural, Chile 67(1): 55-80.

Parin NV, Mironov AN and KN Nesis. 1997. Biology of the Nazca and Sala y Gómez submarine ridges, an outpost of the Indo-West Pacific fauna in the Eastern Pacific Ocean: composition and distribution of the fauna, its communities and history. In: Gebruk AV et al. (ed.). The biogeography of the oceans. Advances in Marine Biology 32:145-242.

Pereira JC, Chaves R, Bastos E, Leitão A, Guedes-Pinto H. 2011. An efficient method for genomic DNA extraction from different molluscs species. International Journal of Molecular Sciences 12(11):8086-8095. DOI: 10.3390/ijms 12118086

Ponder WF. 1998. Family Mitridae. In: Beesley PL, Ross GJB, Wells A (eds.) Mollusca: the southern synthesis. Fauna of Australia. Vol. 5. Part B. Melbourne: CSIRO Publishing, 841-842.

Rogers AD. 2018. The Biology of Seamounts: 25 Years on. Advances in Marine Biology 79: 137 pp. DOI: 10.1016/bs.amb.2018.06.001 
384 Spalding MD, Fox HE, Allen GR, Davidson N, Ferdaña ZA, Finlayson M, Halpern BS, Jorge MA, 385 Lombana A, Lourie SA, Martin KD, McManus E, Molnar JR, Recchia CA, Robertson J.

386 2007. Marine ecoregions of the world: a bioregionalization of coastal and shelf areas. BioScience

$387 \quad$ 57:573-583. DOI: 10.1641/B570707 


\section{Figure 1}

Study area

Map of the study area comprising Desventuradas Islands and seamounts from Salas y

Gómez, Nazca Ridge and Juan Fernández Archipelago. Gray triangles: sampled points during CIMAR 22 cruise. Red triangles: seamounts (SF5, SF6 and SF9) where Atrimitra isolata sp. $\mathrm{n}$. was collected. Red circle: seamount SF2, in which Atrimitra isolata sp. n. was observed in situ. The pink areas represent marine protected areas (MPAs). NDMP=Nazca-Desventuradas Marine Park, EEZ= Exclusive economic zone. Credits for the map: A. Mecho.

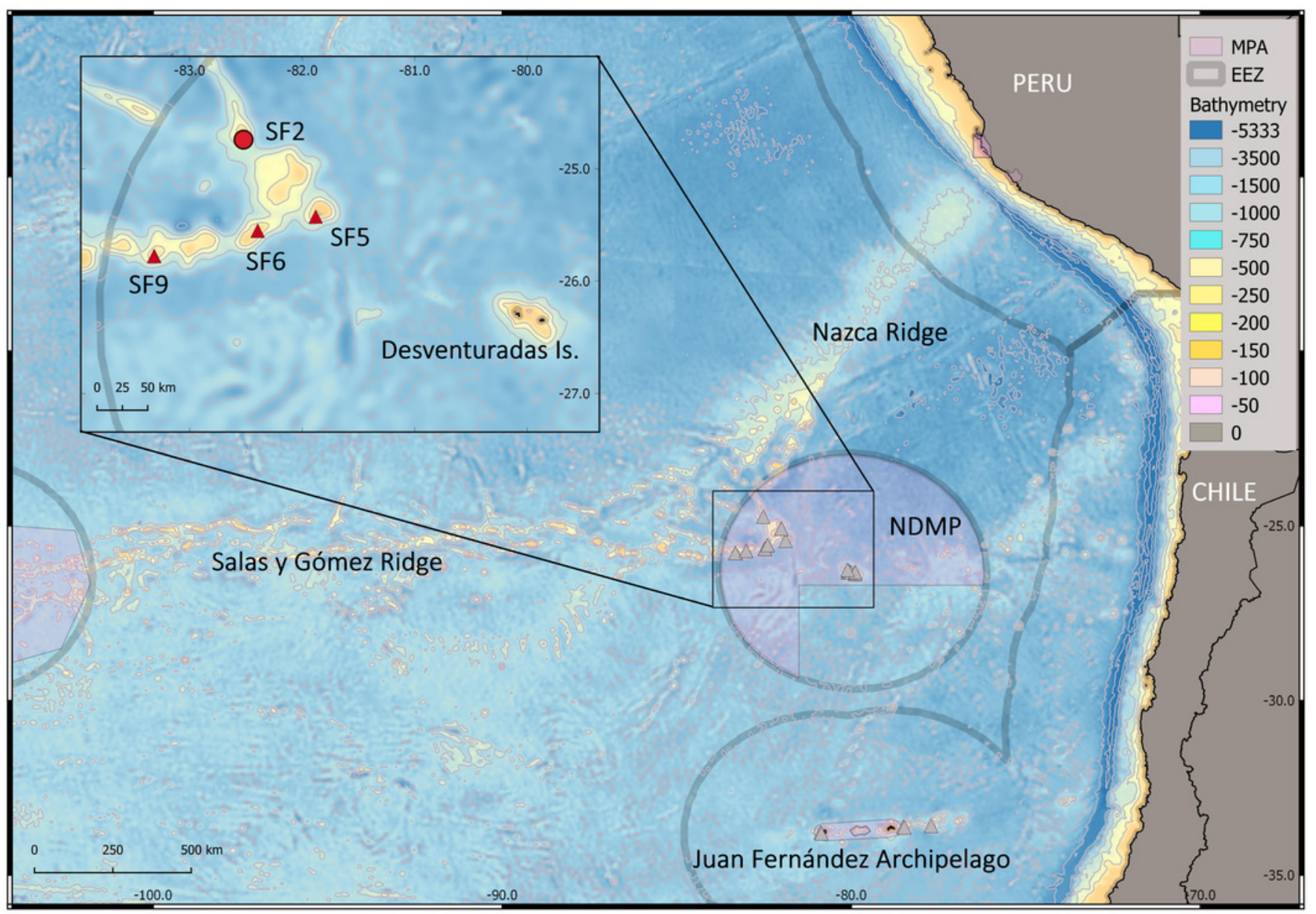




\section{Figure 2}

Type material.

Atrimitra isolata sp. n. (A-D) holotype MNHNCL 203730, Seamount SF 9 off Chile, Lat. $-25.7774^{\circ}$, Long. $-83.163^{\circ}, 200 \mathrm{~m}$ depth. (E-F) paratype 1 MNHNCL 203731, same as holotype. (G-H) paratype 2 CIDA 126,574, same as holotype. Atrimitra idae (I) holotype NMW 1955.158.00100, Point Loma, Baja California, USA. A: abapertural view, B: apertural view, C: side view, D: view of the protoconch and first whorls, E: abapertural view, F: apertural view, G: abapertural view, H: apertural view, I: apertural view.

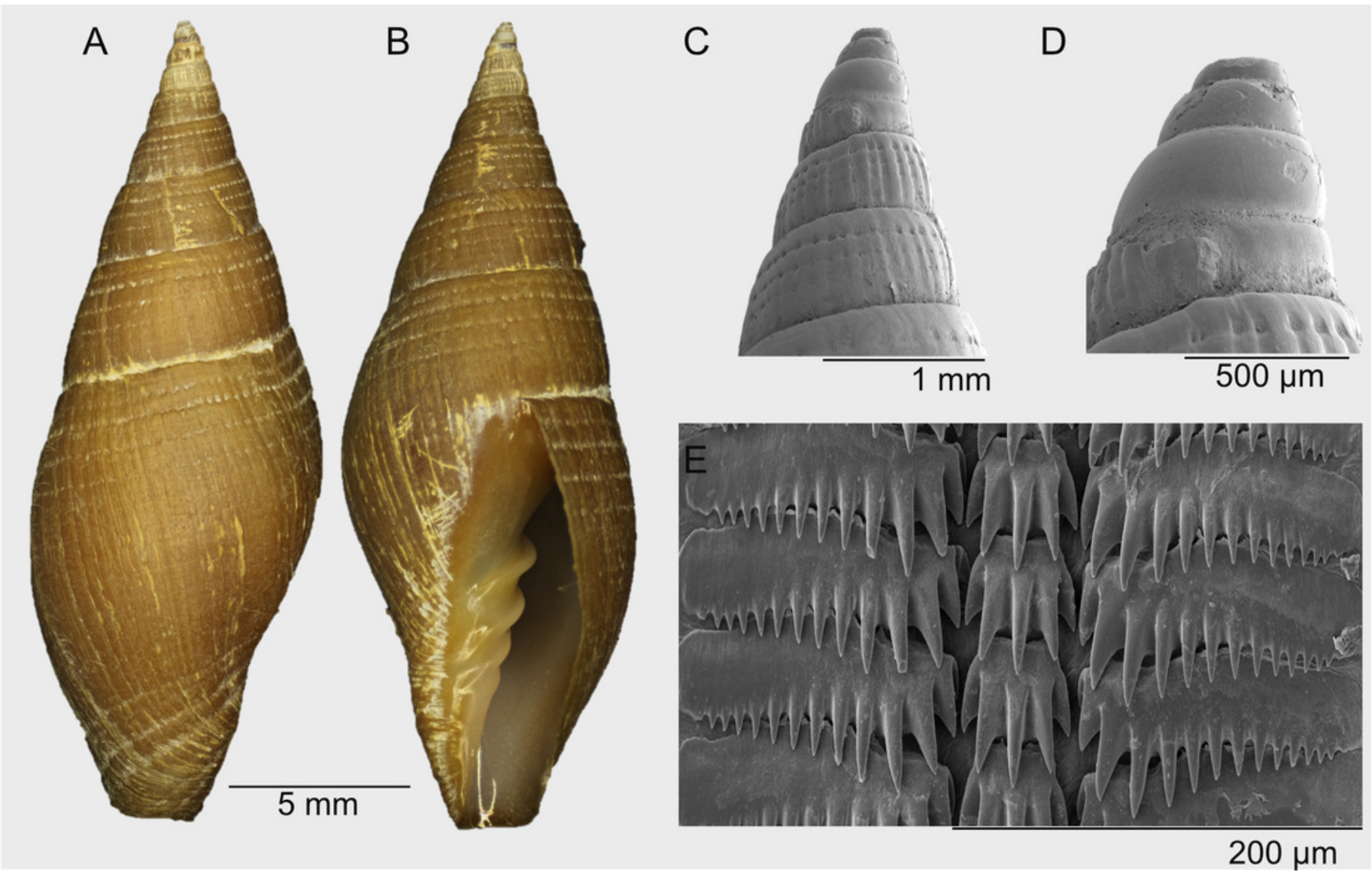




\section{Figure 3}

Radula and protoconch SEMs

Atrimitra isolata sp. n. (A-E) paratype 13 SCBUCN 7030, Seamount SF9 off Chile, Lat. $-25.7774^{\circ}$, Long. $-83.3163^{\circ}, 200$ m depth. A: abapertural view, B: apertural view, C: SEM of the radula, D: SEM side view of the protoconch, E: SEM side view of the first whorls, showing details of the fenestrate sculpture and axial ribs.
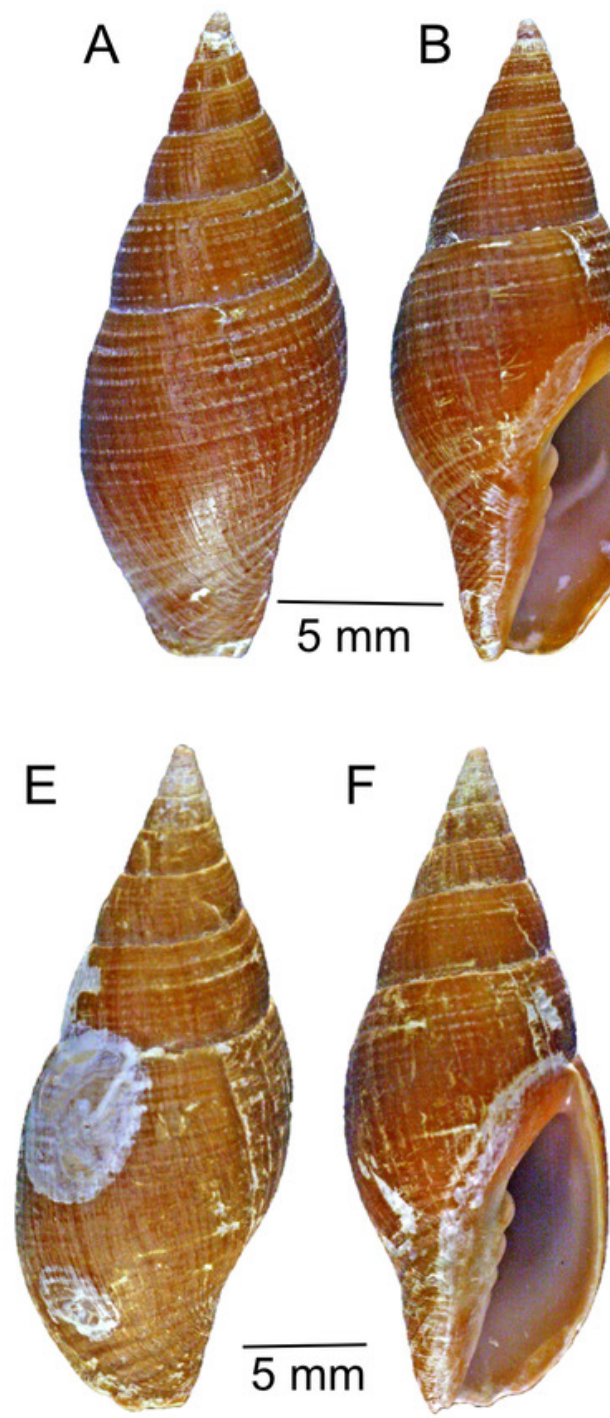
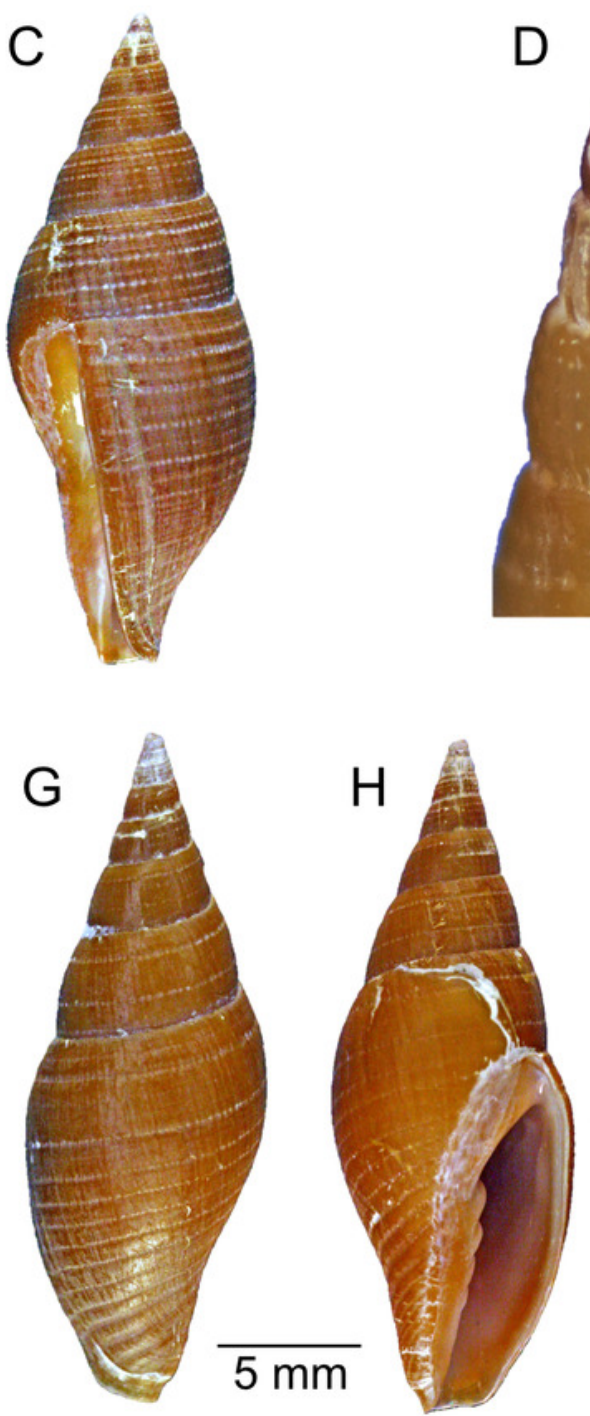
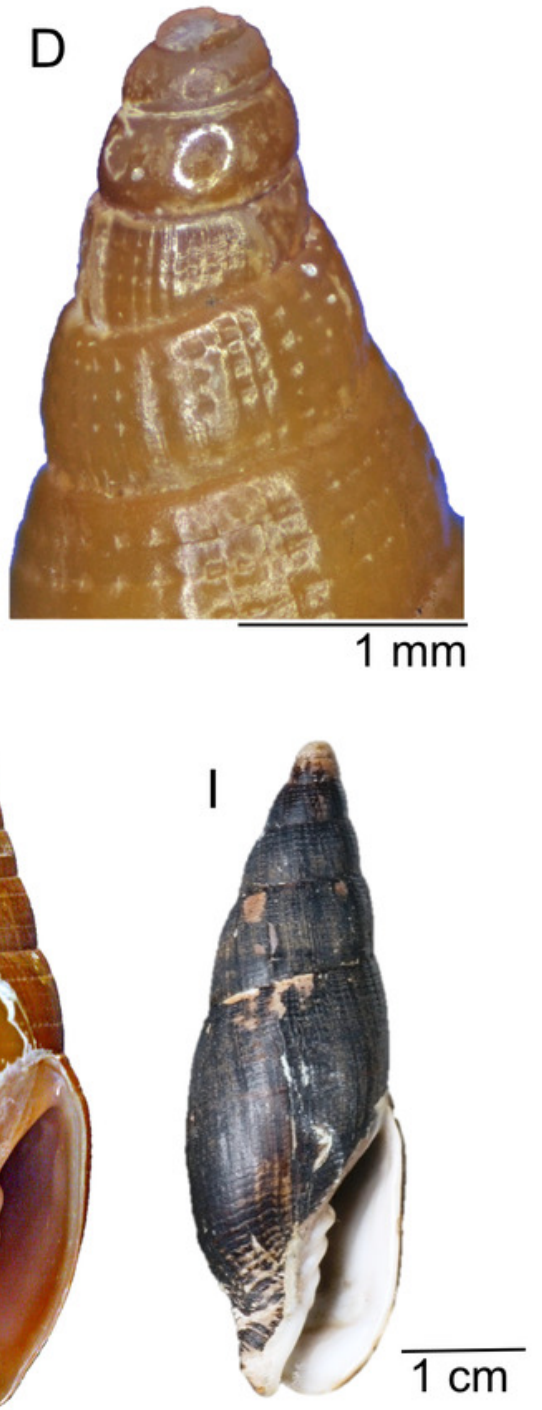
Figure 4

Comparative species

Comparative species. (A-C) Strigatella coronadoensis, holotype SDMNH 44409-667, southeastern end of Los Coronados Islands, Baja California, Mexico. (D-F) Atrimitra semigranosa Arica, Parinacota Region, Chile, RAS collection. (G-I) Atrimitra orientalis Lobos de Afuera Islands, Peru, RAS collection. A: abapertural view, B: apertural view, C: side view, D: abapertural view, E: apertural view, F: side view, G: abapertural view, H: apertural view, I: side view. 

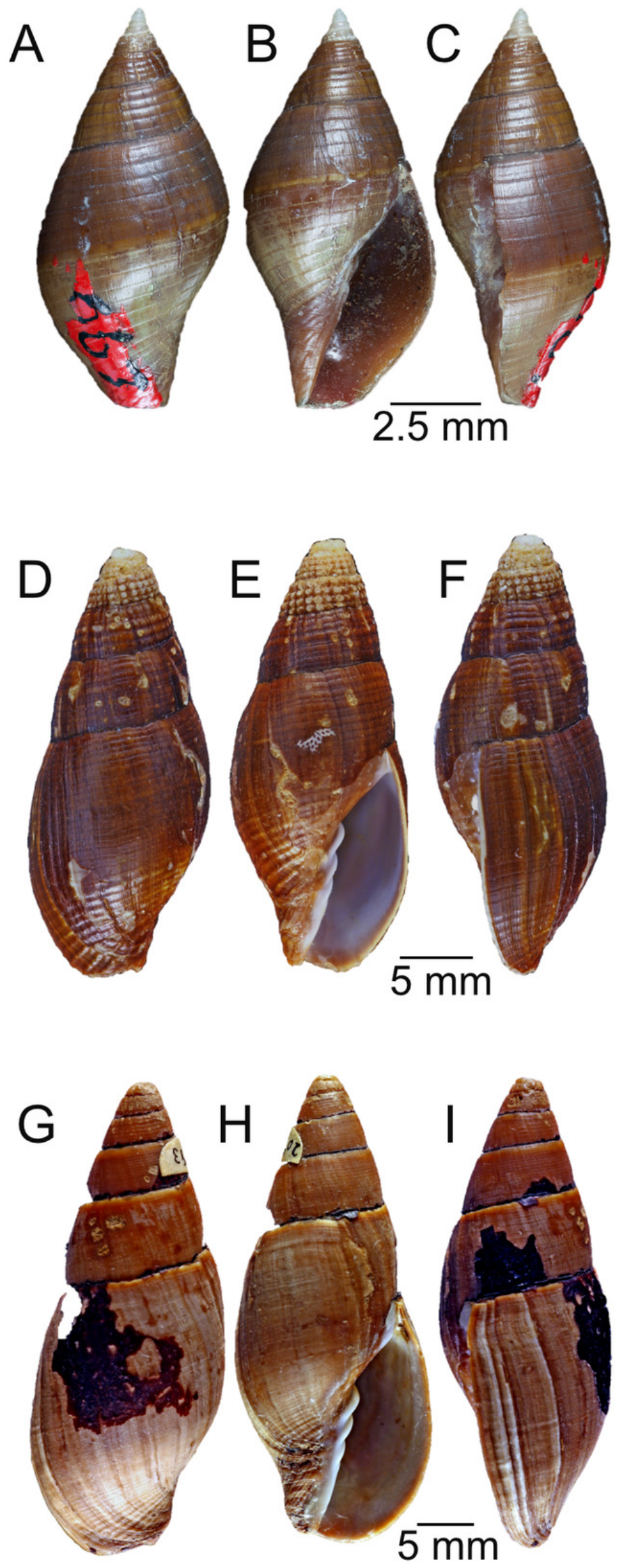

Peer) reviewing PDF | (2018:11:32763:3:0:NEW 4 Nov 2019) 


\section{Figure 5}

Habitat

Images taken with a ROV at the sites where Atrimitra isolata sp. n. was spotted within the Nazca-Desventuradas Marine Park. (A) summit of seamount SF6, $175 \mathrm{~m}$ depth, regular continuous homogeneous bottom with little relief, coarse sand dominated by sea pens (Protoptilum sp.), sea anemones (Hormathia sp. and Cerianthidae) and echinoids (Stereocidaris nascaensis). (B) summit of seamount SF9, $200 \mathrm{~m}$ depth, regular continuous homogeneous bottom with little relief , coarse sand and maërl-rhodoliths, dominated by sponges and sea anemones (Hormathia sp. and Cerianthidae). (C) live specimen of Atrimitra isolata sp. $\mathrm{n}$. on the summit of seamount SF2, $280 \mathrm{~m}$ depth, irregular rock bottom with structures fractured, faulted and folded, dominated by sea pens (Scleroptilum sp.) and hydrozoans (Stylaster marenzelleri). Image credits: Matthias Gorny, OCEANA. 

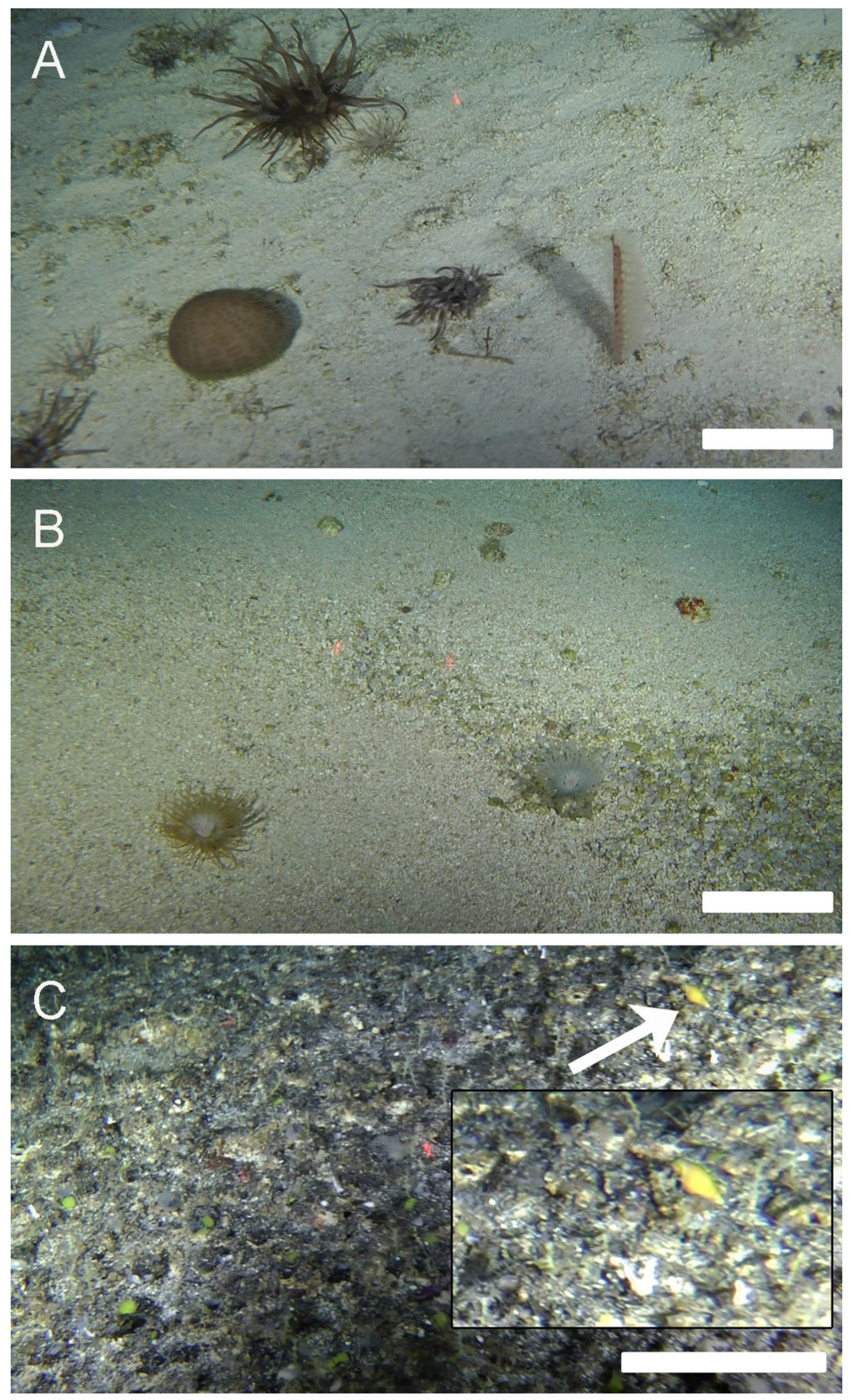

Peer) reviewing PDF | (2018:11:32763:3:0:NEW 4 Nov 2019) 
Figure 6

Commensal limpet

Detail of a hipponicid limpet attached to the shell of Atrimitra isolata sp. n., paratype 8 SCBUCN 7033.

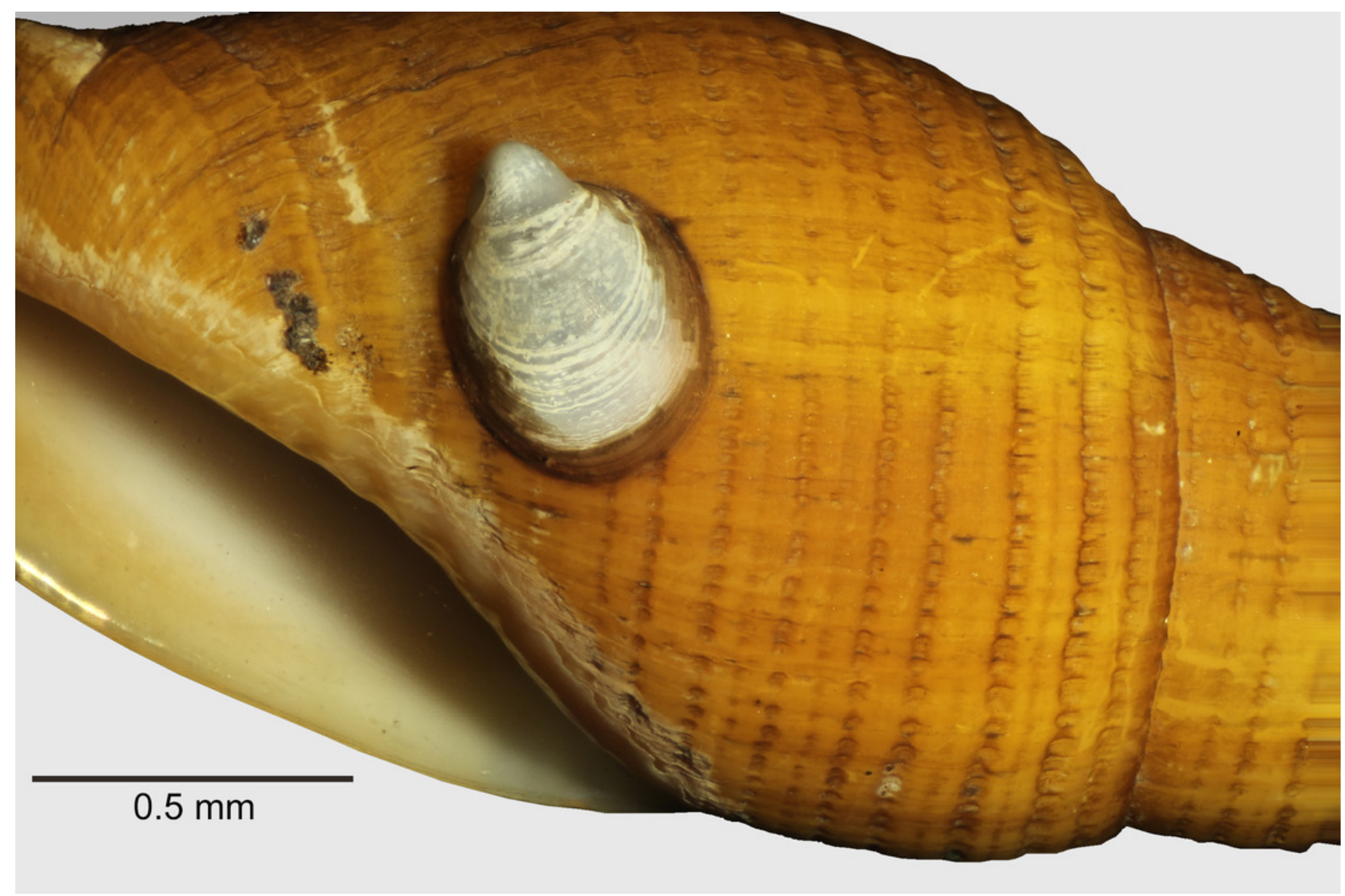

